OPEN ACCESS

Edited by: Hector Perea, Complutense University of Madrid,

Spain

Reviewed by:

Andrea Zanchi,

University of Milano-Bicocca, Italy John Walsh,

University College Dublin, Ireland

*Correspondence:

Victor Tendero-Salmerón vtendero@ugr.es

Specialty section:

This article was submitted to Structural Geology and Tectonics, a section of the journal Frontiers in Earth Science

Received: 24 December 2020 Accepted: 19 March 2021

Published: 13 April 2021

Citation:

Tendero-Salmerón V, Lafosse $M$, d'Acremont E, Rabaute A, Azzouz O,

Ercilla G, Makkaoui M and Galindo-Zaldivar J (2021) Application of Automated Throw Backstripping

Method to Characterize Recent Faulting Activity Migration in the Al Hoceima Bay (Northeast Morocco):

Geodynamic Implications.

Front. Earth Sci. 9:645942.

doi: 10.3389/feart.2021.645942

\section{Application of Automated Throw Backstripping Method to Characterize Recent Faulting Activity Migration in the Al Hoceima Bay (Northeast Morocco): Geodynamic Implications}

\author{
Victor Tendero-Salmerón ${ }^{1 *}$, Manfred Lafosse ${ }^{2,3}$, Elia d'Acremont', Alain Rabaute'2, \\ Omar Azzouz ${ }^{4}$, Gemma Ercilla ${ }^{5}$, Mohamed Makkaoui ${ }^{4}$ and Jesus Galindo-Zaldivar ${ }^{1,6}$ \\ ${ }^{1}$ Instituto Andaluz de Ciencias de la Tierra (CSIC-UGR), Granada, Spain, ${ }^{2}$ Sorbonne Université, CNRS-INSU, Institut des \\ Sciences de la Terre Paris, ISTeP UMR 7193, Paris, France, ${ }^{3}$ Tectonic and Structural Geology Groups, Department of Earth \\ Sciences, Utrecht University, Utrecht, Netherlands, ${ }^{4}$ Laboratoire de Géologie Appliquée, Faculté des Sciences, Université \\ Mohammed ler, Oujda, Morocco, ${ }^{5}$ Instituto de Ciencias del Mar, Continental Margins Group, Consejo Superior de \\ Investigaciones Científicas (CSIC), Barcelona, Spain, ${ }^{6}$ Departamento de Geodinámica, Universidad de Granada, Granada, \\ Spain
}

Automation of the throw backstripping method has proven to be an effective tool for the determination of the evolution of tectonic activity in wide fault zones. This method has been applied to the Al Hoceima Bay (southwesternmost Mediterranean, Alboran Sea) for a time period covering the last $280 \mathrm{kyr}$ on 672 faults imaged on 265 highresolution seismic reflection profiles. This area was affected by major earthquakes and corresponds to a transtensional basin deformed by growth faults. The automated application of throw backstripping allowed for a faster deciphering of the migration of tectonic activity. Results show a westward migration of the deformation with quickly increasing deformation rates in the most recent time frames near Al Hoceima, one of the most populated cities. This migration is in agreement with the current seismicity, the GPS data, and recent brittle deformation data. Vertical throw rates of up to $0.47 \mathrm{~mm} /$ year have been calculated, for the most recent time periods, in segments of the Bokkoya fault zone. The westward migration of the deformation fits with the reconstruction suggested by the westernmost Mediterranean geodynamic models during the Pleistocene epoch, and it might be the consequence of the interaction between the northwest (NW) movement of the South Alboran indenter and the back Rif south-westward displacement. The highly accurate constraints of the evolution of the tectonic activity offered by this automation will substantially improve the seismic hazard assessment.

\footnotetext{
Keywords: active tectonics, throw backstripping, faulting migration, marine faulting, Alboran Sea
} 


\section{INTRODUCTION}

Active faults associated with earthquakes are generally characterized by the deformation of very recent deposits and geomorphological signatures, such as continuous scarps, linear valleys, or low sinuosity mountain fronts (e.g., Wesnousky, 1986; Keller and Pinter, 1996). These geomorphological features are not very marked in young and small-scale faults because of the minor accumulated deformation, even when very active. Moreover, smaller faults can remain generally undetected as blind structures that do not reach the surface. Consequently, recent small-scale and blind faults are not usually the target of palaeoseismic studies which generally focus on faults with a well-preserved record of major earthquakes, even if their most recent activity is decreased (Cornell, 1968; McCalpin, 2009 and references therein). Another issue is the importance of differentiating between neotectonics and active tectonic activity, and between recent faults and newly formed faults. In faulty submarine basins with considerable sedimentation rates, growth faults are the best candidates for study. Their activity creates significant vertical movement affecting deposits that can be quantified using deformed regional reference markers in both fault blocks (e.g., Worrall and Snelson, 1989; Childs et al., 1995; Mansfield and Cartwright, 1996; Cartwright et al., 1998; Back et al., 2006; Baudon and Cartwright, 2008). The best method for determining the incremental throw of synsedimentary faults, such as growth faults (Carver, 1968) through time is the throw backstripping (Petersen et al., 1992; Childs et al., 1993, 1995) method. In the study of the evolution of fault systems, the latter has been employed as a useful tool in many geological settings (Jackson et al., 2017, and references therein).The throw backstripping has been applied over long periods of time (several millions of years) in fault systems (Nicol et al., 1997; Meyer et al., 2002; Walsh et al., 2003; Giba et al., 2010; Phillips et al., 2018) and over short periods of time (Nicol et al., 2005, 2006).

In contexts of fast migration of deformation, such as those of orogenic wedges (e.g., Davis et al., 1983; Carrapa, 2009) or back-arc basins (Milia and Torrente, 2018), a quick rise and abandonment of faults generally occurs. Small faults may experience an acceleration in the deformation rate, with the increase of the associated seismic hazard (Goldsworthy and Jackson, 2001; Galadini and Messina, 2004). Since the distance to the source of earthquakes is a key factor to evaluate seismic hazard (e.g., Cornell, 1968; Wang, 2011, and references therein), it is important to understand the evolution of the fault systems and the location where the active deformation migrates to. Moreover, in complex and slowly deforming continental crusts that are affected by wide fault zones, the identification and evolution of recent active deformation may be a complex subject. This is the case of the Nekor basin, in northeastern Morocco (Figure 1). This Neogene basin, located in the southern Alboran Sea (westernmost Mediterranean), is surrounded by the Gibraltar Arc which is formed by the Betic-Rif Cordilleras (Comas et al., 1992; Figure 1). This basin is considered a key area as it is located at the plate boundary between Africa and Eurasia (e.g., Vernant et al., 2010; Lafosse et al., 2020). It constitutes the tip of a strike-slip zone (Al Idrissi fault system) that has become incipient since 1.8 Ma (Lafosse et al., 2020), and where the active left-lateral displacement recorded along the major Al Idrissi fault system is transmitted to the Rif Cordillera in Morocco, accompanied by the development of new faults (Galindo-Zaldivar et al., 2018). In the context of the convergence between the Eurasian and African plates, the Alboran Domain extending up to the $\mathrm{Al}$ Hoceima region is undergoing a westward displacement (Balanyá et al., 2007; Corsini et al., 2014; GonzálezCastillo et al., 2015). The recent geodynamic evolution has been related to different lithospheric processes, with two groups of hypotheses; on one side, those related to a slab roll-back of the retreating subduction zone starting from the Miocene (Blanco and Spakman, 1993; Ruiz-Constán et al., 2011; Spakman et al., 2018, and references therein), and on the other, those related to lithospheric delamination (e.g., Seber et al., 1996; Mancilla et al., 2013; Baratin et al., 2016). At a local scale, several points are under discussion, such as (i) the position of seismicity and its origin, which includes the biggest onshore and offshore earthquakes in the region for the last few decades (Mw 6.0 in 1994, Mw 6.4 in 2004, and Mw 6.3 in 2016, Figure 2; El Alami et al., 1998; Stich et al., 2005; Galindo-Zaldivar et al., 2009, 2018; Van der Woerd et al., 2014; Gràcia et al., 2019), and (ii) the driving force and chronology of the westward movement of the Rifian block (Koulali et al., 2011; Petit et al., 2015).

This study concerning offshore faults from Pleistocene epoch to the present day in the Al Hoceima area aims to quantify their deformation rates through time. For that purpose, we automated the throw backstripping method (Petersen et al., 1992) in order to analyze a high number of faults efficiently. $\mathrm{Al}$ Hoceima Bay constitutes a key area of the Eurasian-African plate boundary, and the results bring new data enhancing regional tectonic modeling and allowing for better estimations of coastal seismic hazard.

\section{GEOLOGICAL SETTING}

The Gibraltar Arc is composed by the Betic Cordillera in the north and the Rif in the south, connected though the Gibraltar Arc (Figure 1). Both cordilleras are composed of stacked nappes divided into internal zone (Alboran Domain) and external zone (sediments from the Iberian and African paleomargins) separated by flysch units. In the Rif, the internal zone is mainly formed by allochthonous metamorphic complexes that include paleozoic rocks emplaced during the Eocene-Oligocene Alpine tectonic phase. From top to bottom, these complexes are named, sebtide and ghomaride (Chalouan, 1986; Chalouan et al., 2008). Moreover, the dorsal and predorsal complexes (Andrieux, 1971; Frizon de Lamotte, 1985), which are mostly made up of carbonates, also belong to the internal zone. The flysch units are characterized by detrital sediments deposited in the trench between the internal and external zones from Cretaceous to Oligocene (Frizon de Lamotte, 1985). The external zones are parautochthonous rocks that are composed of carbonate and pelitic mesozoic and cenozoic sequences, some of them with low to medium grade of metamorphism (Andrieux, 1971). 


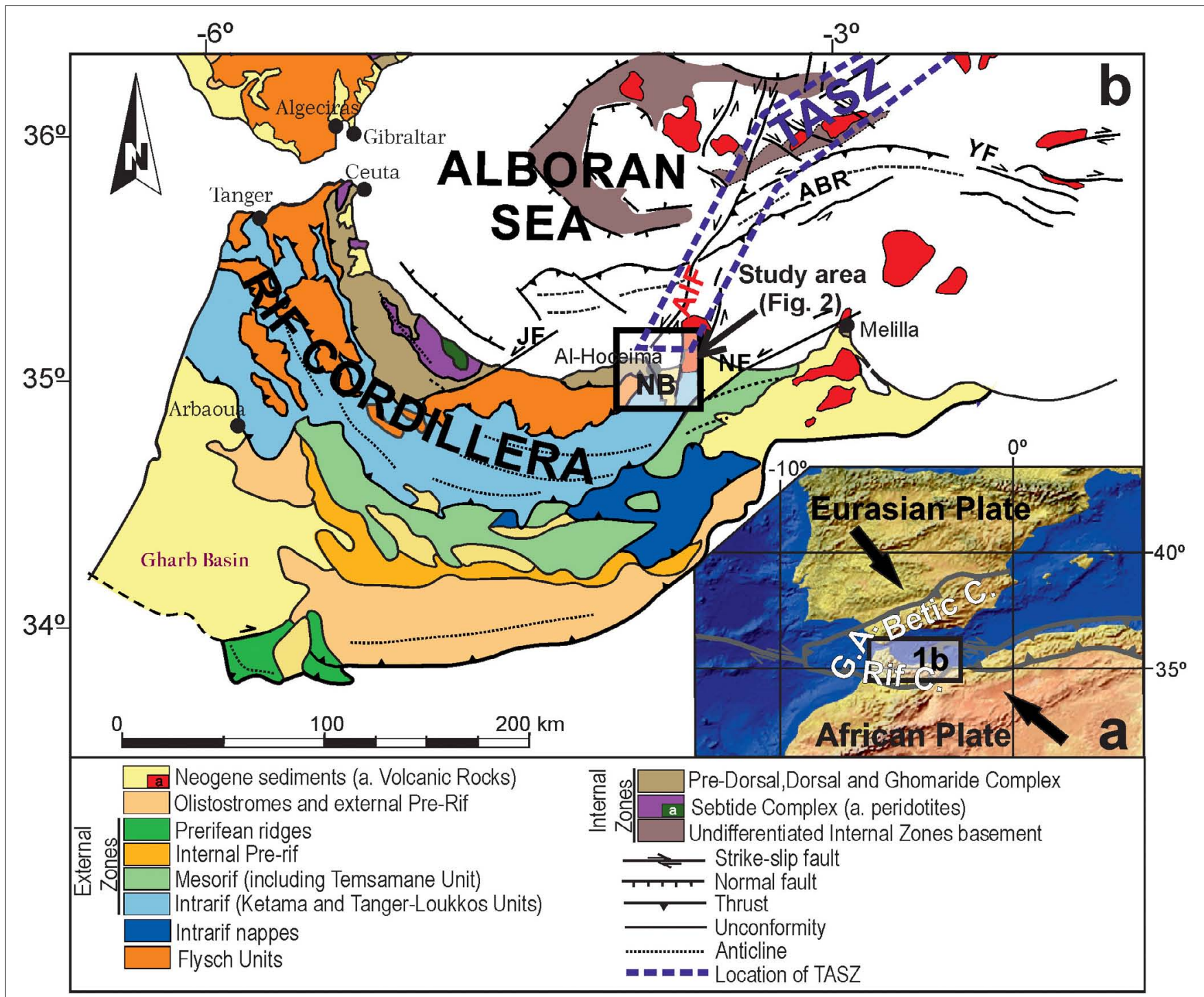

FIGURE 1 | Location of the study area. (a) Regional setting. Plate boundaries from Do Couto et al. (2016). G. A., Gibraltar Arc; (b) Geological map of Southern Alboran Sea and Rif Cordillera (modified from Galindo-Zaldívar et al., 2015).

The Alboran Sea is a Neogene basin that is surrounded by the Gibraltar Arc (Figure 1; Comas et al., 1992). The thin continental crust that constitutes its basement is made up of alpine metamorphic rocks of the Alboran Domain (internal zones) (Comas et al., 1992; García-Dueñas et al., 1992; Gomez de la Pena et al., 2018), and above it, the Miocene to Quaternary sedimentary infill is mainly detritic (Comas et al., 1992; Juan et al., 2016). The westward displacement of the Alboran Domain is well-known since the study by Andrieux (1971), and it has been corroborated with GPS data (Koulali et al., 2011; Palano et al., 2015). During the Miocene epoch, crustal thinning took place followed by a compression in the Late Tortonian Age (Comas et al., 1992; Do Couto et al., 2016). Both the westward displacement and the crustal extension has been explained by the following two groups of lithospheric models: slab roll-back of the retreating subduction zone that thinned a previous orogen
(Blanco and Spakman, 1993; Ruiz-Constán et al., 2011; Spakman et al., 2018, and references therein) and mantle delamination of the thickened lithosphere of that orogen (e.g., Seber et al., 1996; Mancilla et al., 2013; Baratin et al., 2016).

The current compression is combined with an orthogonal extension that continues till today (Comas et al., 1992; Vissers et al., 1995; Sanz de Galdeano and Alfaro, 2004; DeMets et al., 2010; Neres et al., 2016). Active strike-slip faults are widely distributed and most of them are grouped in northeast and southwest (NE-SW) left lateral faults (e.g., Al-Idrissi fault zone) and northwest and southeast (NW-SE) dextral faults (e.g., Yusuf fault) (Figure 1). The en échelon NE-SW left lateral strike-slip faults that cross the Alboran Sea and continues in the eastern Betic Cordillera is called the Trans-Alboran Shear Zone (TASZ, Figure 1b; De Larouzière et al., 1988). Recent indentation and block rotation processes (Perea et al., 2018) in the Alboran Sea 


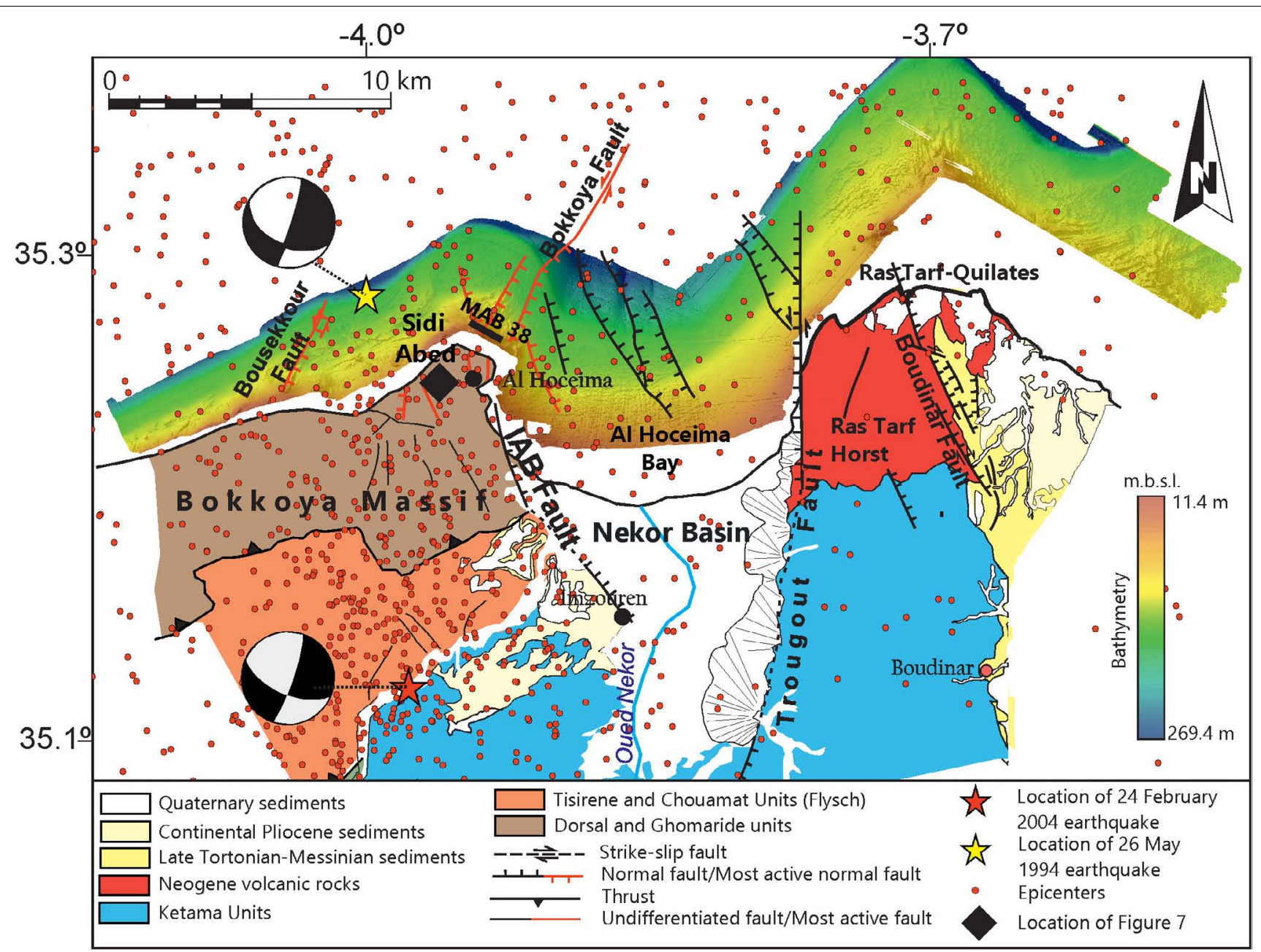

FIGURE 2 | Geological map of Nekor Basin and swath-bathymetry of the Al Hoceima margin from Marlboro-2 Survey (modified from d'Acremont et al., 2014; Galindo-Zaldívar et al., 2015). Seismicity from IGN catalog 2000-2020; earthquakes with Mw > 1.5, and the position of the main shocks of the seismic series of 2004 and 1994 from Calvert et al. (1997) and Van der Woerd et al. (2014). The focal mechanisms of both earthquakes are from Van der Woerd et al. (2014). The location of the outcrop of Sidi Abed presented in Figure 7 and MAB 38 profile is also displayed.

deform the TASZ and explain the conjugate sets of present day right lateral faults (Estrada et al., 2018; d'Acremont et al., 2020) and the initiation of the $\mathrm{Al}$ Idrissi fault zone (Gràcia et al., 2019; d'Acremont et al., 2020; Lafosse et al., 2020).

The southern termination of the Al Idrissi fault zone is a transtensional basin that acts as a horsetail splay in the Nekor basin (Figures 1b, 2; d'Acremont et al., 2014; Lafosse et al., 2016). The study area covers the offshore continental margin of $\mathrm{Al}$ Hoceima Bay (Figure 2) and the northeasternmost part of the onshore Bokkoya Massif margin belonging to the internal zone (Figure 2). This carbonate massif is made up of a thrust-sheet stack of dorsal and ghomaride units (Andrieux, 1971; Chalouan, 1986). The major Nekor fault is located to the south of the Nekor basin (Figure 1b), and it accommodates the southwestward emplacement of the Rif internal zones during the Miocene epoch (Leblanc and Olivier, 1984). The western Nekor basin boundary corresponds to the Imzouren-Ajdir-Boujibar normal faults (Figure 2; Ait Brahim and Chotin, 1990; d'Acremont et al., 2014) that separate the Plio-Quaternary sedimentary Nekor basin infill from the internal zones (Bokkoya Massif), the nappes of Flysch, and the Ketama Unit of the external zones (Azdimousa et al., 1998). The eastern boundary of the Nekor basin corresponds to the Trougout fault (Figure 2), an oblique normal left lateral fault, whose slip decreases southward and that makes the Al Hoceima Bay an asymmetric graben (Ait Brahim and Chotin, 1990; Galindo-Zaldivar et al., 2009; Lafosse et al., 2016, 2020). Trougout fault separates the basin from the Ketama Unit and the Upper Miocene volcanic rocks of Ras Tarf cape (Figure 2; El Azzouzi et al., 1999). The Nekor basin is filled with a 400-500 m thick Plio-Quaternary sequence of overlying undated marls (Galindo-Zaldivar et al., 2009). This basin is considered as a transtensional basin with a rhombohedral shape (Lafosse et al., 2016).

Offshore, the whole bay presents a set of NW-SE normal faults that cross the Bay between the Bokkoya and the Trougout faults (Figure 2; Calvert et al., 1997; Lafosse et al., 2016). This network 
of normal NW-SE to north-south (N-S) faults located in the Bay has a syn-sedimentary character (Lafosse et al., 2016, 2018) similar to that of the growth faults, where most of them are normal and are quickly buried by sedimentation. The Bokkoya fault is considered a normal NE-SW left lateral fault (Calvert et al., 1997; d'Acremont et al., 2014; Lafosse et al., 2016). The Bokkoya fault and the offshore prolongation of the Trougout fault can connect to the southern termination of the Al Idrissi fault and other parallel faults (d'Acremont et al., 2014; Lafosse et al., 2016; Galindo-Zaldivar et al., 2018; Gràcia et al., 2019). Westward, outside the Nekor basin, the Bousekkour fault is interpreted as a left-lateral normal fault parallel to the Bokkoya fault (Figure 2; d'Acremont et al., 2014).

While offshore displacements are significant (d'Acremont et al., 2014; Lafosse et al., 2016; Gràcia et al., 2019), it is difficult to observe any clear displacement onshore (Figure 2; Galindo-Zaldivar et al., 2009). The epicenters of the earthquake reveal a deep tectonic activity and are mainly distributed west of the Imzouren-Ajdir-Boujibar normal faults, with the biggest earthquakes recorded in the last few decades (Figure 2; 1994 and 2004 main shocks; El Alami et al., 1998; Biggs et al., 2006; Van der Woerd et al., 2014). The easternmost part of the Bokkoya Massif provides field observations on recent and active faults in the region (Stich et al., 2005; Galindo-Zaldivar et al., 2009; Van der Woerd et al., 2014; Galindo-Zaldívar et al., 2015). This region is deformed by recent or active minor fractures (GalindoZaldivar et al., 2009). These brittle deformations are evidences of a present day, rough east-west (E-W) extension orthogonal to the coast line. This appears to be in contrast with the occurrence of strike-slip focal mechanisms at depth, which could be due to the existence of a crustal detachment that decouples some deeper deformation zones from more shallow ones (GalindoZaldivar et al., 2009; Galindo-Zaldívar et al., 2015). In contrast, the Trougout fault in the eastern part of Al Hoceima Bay presents a straight relief of $13 \mathrm{~km}$ length, but there is no significant seismicity and only local outcrops show some evidences of a recent fault activity (Poujol et al., 2014).

\section{DATA AND METHODS}

\section{Data}

Multichannel high-resolution seismic reflection and multibeam bathymetry were acquired during Malboro-2 survey along 265 profiles, which cover $190 \mathrm{~km}^{2}$ from the eastern limits of $\mathrm{Al}$ Hoceima Bay to $14 \mathrm{~km}$ westward of Ras El Abid Promontory continental shelf (Figure 3). These data were acquired using a 250-500 J Sparker source and a six-channel streamer, with a vertical resolution of $1 \mathrm{~m}$. The swath bathymetry was acquired in Marlboro-2 survey by means of a shallow-water Reson 8101 system. It has a horizontal definition of $5 \mathrm{~m} / \mathrm{pi}$ and a vertical resolution of $0.5 \mathrm{~m}$ at depths of above $-100 \mathrm{mbsl}$ (d'Acremont et al., 2014; Lafosse et al., 2016).

\section{Methods}

To quantify the fault throw, a methodology based on the displacement/throw backstripping developed by Petersen et al.
(1992) was used. This method makes no assumptions about the patterns of throw accumulation or the style of fault growth (Jackson et al., 2017), and consists of measuring the vertical throw at regular intervals along the fault and across multiple stratigraphic horizons. Each throw is calculated by removing the throw accumulated on the youngest horizon. This allows for the determination of the activity of the fault through time (Petersen et al., 1992; Childs et al., 1993; Nicol et al., 1997). This method was applied on 672 faults determined by Lafosse et al. (2016). Although most of the faults inside the Al Hoceima Bay are normal, some of them have strike-slip components (Lafosse et al., 2016, 2020). Onshore, the normal faults located at Sidi Abed (Figures 2, 7) present striae with pitch $>70^{\circ}$. In the Trougout fault, which outcrops onshore, estimations of the horizontal and vertical components have been done for the last 7,190 years (Poujol et al., 2014), which provide a vertical/horizontal ratio of $\sim 1.75$. The vertical throw of the faults that border the basin, such as Bokkoya and Trougout (Lafosse et al., 2020), is big enough to affect the seafloor (Lafosse et al., 2016). Thus, the analysis of the vertical component can be used as an indicator of the fault activity.

In order to determine the age of the fault throw, basin scale stratigraphic surfaces of very low dipping angles have been selected (Figures 3, 4). In the study area, these surfaces represent marine regressive surfaces (MRS) reworked during fast marine transgressions (Lafosse et al., 2018). These surfaces correspond to major sea level drops during the Late and Middle Pleistocene, related to the $100 \mathrm{kyr}$ glacio-eustatic cycles. The three most recent marine regressive surfaces (here named, MRS1, 25 kyr; MRS2, $150 \mathrm{kyr}$; and MRS3, $280 \mathrm{kyr}$, according to sea level variations, as observed by Frigola et al. (2012), and Grant et al. (2014), and identified by Lafosse et al. (2018) have been used to analyze the fault activity since $280 \mathrm{kyr}$. The vertical displacement of these very low dipping surfaces is attributed to fault activity and was measured in two-way-time (TWT) measured in milliseconds (ms). A rough estimation of the vertical throws in meters has been calculated using an average value of propagation velocity for the Quaternary sediments $(1,576 \mathrm{~m} / \mathrm{sec})$ obtained by MartínezGarcía et al. (2017) and sedimentation rates have been considered constant (Martínez-García et al., 2013; Lafosse et al., 2016).

The throw of all the faults of every seismic profile, for the three most recent MRS, were measured. Then, maps of the throw values for each period ranging between each MRS until the present have been generated. Initially, four groups of data were exported from the IHS Kingdom Suite ${ }^{(}$software to the ArcGis $\left.{ }^{(}\right)$software: a shapefile layer with traces of the profiles, three raster layers that correspond to the isopach map for each MRS containing the depth value in TWT expressed in ms, a shapefile layer with fault traces, and a shapefile layer called "fault points." These "fault points" represent the location of each crossing between a fault and a seismic profile (Figure 3). These fault points were obtained from the IHS Kingdom Suite by extracting the upper tip of each fault drawn in each seismic profile. Then, work-flows were created using the model builder tool of ArcGIS as follows:

(i) The depth range at each MRS, for each fault point was extracted. First, the pixels located inside an area of $60 \mathrm{~m}$ 


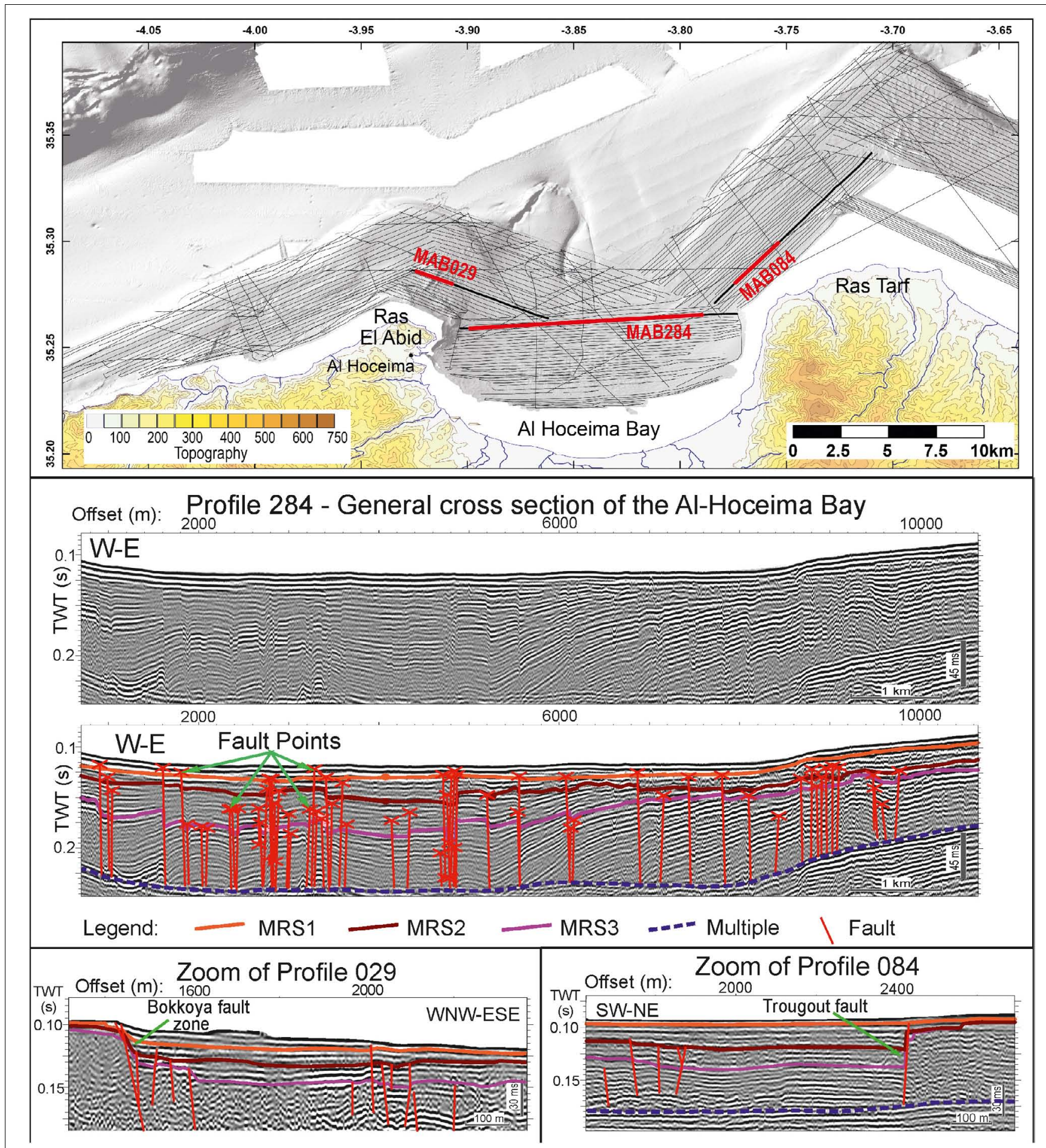

FIGURE 3 | Seismic images of the cross-section of Al Hoceima Bay and details of Bokkoya and Trougout faults on multibeam bathymetric map, including the location of the high-resolution seismic reflection profiles used for this study (Marlboro-2 survey). Profile 284 has been displayed with and without interpretation as a general overview of the Bay. The red "X" represents the fault points displayed in a seismic profile. Magnification of Profiles 29 and 84 are intended to present the Bokkoya fault and the Trougout fault.

around the trace of the profiles were extracted for each MRS raster layer (Figure 4) with the buffer tool. With the newly extracted rasters of MRS1, MRS2, and MRS3, a focal statistics tool was applied using a range parameter that sets a radius of $60 \mathrm{~m}$. The tool calculates the difference between the maximum and minimum depth values using 

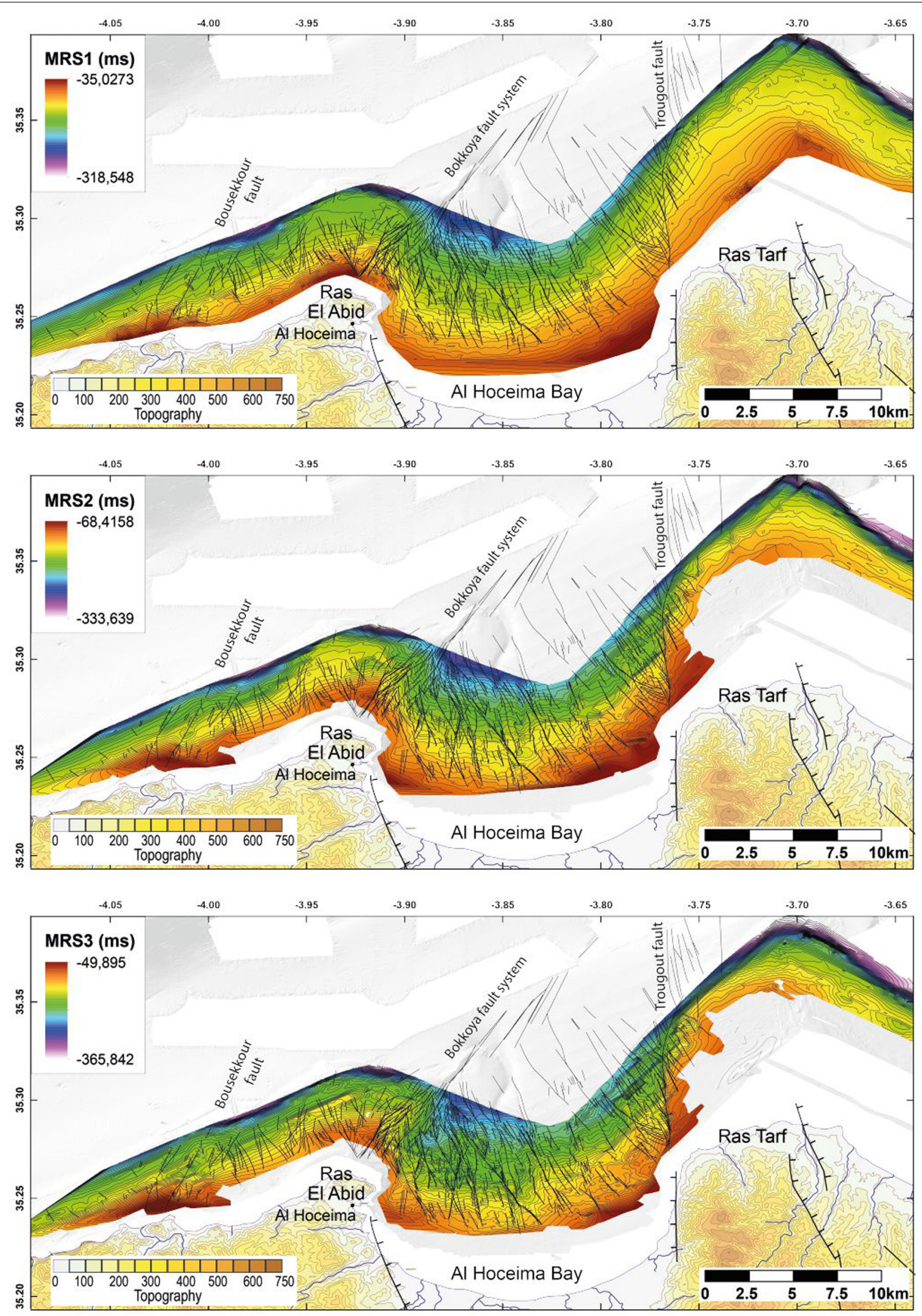

FIGURE 4 | Marine regressive surfaces (MRS) used for the throw analysis. The fault traces considered are also depicted. 
the values of each pixel inside a $60 \mathrm{~m}$ radius and assigns that value to a central pixel in the new raster layer. The radius of $60 \mathrm{~m}$ was chosen after testing different distances. This radius is adequate since the faults are high-angle normal faults (most of them with dip $>65^{\circ}$ ) and some of them are vertical faults. It also minimizes local errors like bending associated to faulting. Thus, the application of this method is optimal in high dipping faults. Since the values of the pixels are the depth of the MRS, the range is proportional to the paleo-topographic vertical displacement. The maximum difference corresponds to the throw generated by the fault in locations closer to a fault (considering the slope is gentle on all the surfaces, see points below). After that, the range was extracted at each fault point.

(ii) We determined whether a fault cuts each MRS at each fault point. Part of the fault points belong to faults that do not cut any MRS used in this study. The depth value of each MRS was extracted using the "extracted multi values to points" tool. In the attribute table of the layer, three new fields were created to flag the position of fault tips relative to each MRS. When the faults do not cut any MRS, a throw value of 0 is assigned.

(iii) The throw of each fault point and each interval following the throw backstripping method was calculated. For the oldest intervals, the throw accumulated at the youngest horizon was removed.

(iv) We made raster layers of the throw of the area for each MRS interval. The attribute table of the fault points of the layer has all the throw data calculated in the previous steps.

Finally, once the throw maps were obtained, throw rate maps were created by transforming TWT into depth and then dividing the period of time between MRS. These throw rates only consider the vertical deformation associated with the faults.

During the process, negative values of fault throw were produced. In the results, negative values are not considered in the throw backstripping method, since throw values related to the fault activity are supposed to be positive except in cases where inversion tectonics might have occurred. Inversion is considered to be an uncommon process in the context of short-time periods and a homogeneous regional pattern is expected in most of the faults; therefore it is assumed that the tectonic regime remained constant since $280 \mathrm{kyr}$. Negative values with irregular patterns are related to sedimentary and erosion processes like the shelf edges, talwegs, and canyons (e.g., the canyon located northeast (NE) of Al Hoceima, Figure 5), where younger MRS locally can show high slopes and, consequently, higher depth ranges with respect to the older ones. For example, in the Canyon, submarine erosion increases the local slope through time, and when throw backstripping was applied, negative values were obtained in the MRS2 and MRS3. Other examples related to sediment process are the uncompacted sedimentary wedges in the central part of the basin, where fluvial sediments are deposited, which can locally increase the throws of MRS1 or MRS2, which lead to negative values. Some situations lead to poor vertical resolutions, which cause negative values, such as low vertical offsets or thickness variations from either part of the fault zones. Other negative values may be related to errors in the fault locations, irregularities in the reference surfaces (MRS), or artifacts generated during the interpolation of these surfaces. In most of the cases, negative values are between -4 and $0 \mathrm{~ms}$ because these are related to small faults and small throws. TWT shifts between seismic lines are the minimum because the data were recorded during the same survey in similar and good sea conditions. Nevertheless, since the aim of this work is to consider the tectonic activity data and then to analyze the positive throw values related to the tectonic activity, the maps only show the neighborhood of the faults to avoid noise interferences (Figures 5, 8).

\section{RESULTS}

Faults in Al Hoceima Bay are of high angles, and sometimes reach to a vertical dip. The distribution of fault throws in the study area through time highlights the variation of the fault activity, and it is represented by the timing throw maps. Taking into consideration the time period comprised by each map, and a constant sedimentation rate, the data presented here have been used to estimate the average throw rates. The faulting throw rate maps provide a tool to analyze the acceleration and slowing of tectonic activity in each sector affected by the migration of the deformation.

\section{Deformation Distribution Through Time}

Three timing maps of the vertical displacement have been established (Figure 5) in TWT (ms), since 280 kyr. These detailed vertical displacement maps allowed us to identify high throw values focused along the faults. The high values that were observed in a distributed pattern over broad sectors will not be considered as these are not related to fault activity, but to the presence of high slopes at the edge of the shelf and are to be attributed to canyon and platform edge processes (north of $\mathrm{Al}$ Hoceima city and north-west of Trougout fault).

The vertical displacement between MRS3 (280 kyr) and MRS2 (150 kyr) (Figure 5C) shows that deformation is distributed throughout the Al Hoceima Bay, since most of the faults have significant values (average of 4.1-11.7 ms, Figure 6; 4-9 m, peak values over $15 \mathrm{~ms}, 11.8 \mathrm{~m}$, Figure $5 \mathrm{C}$ ). The high values are concentrated along lines which roughly match the fault zones, values up to $21 \mathrm{~ms}$ occur at the Trougout fault zone $(16.5 \mathrm{~m})$ up to $18 \mathrm{~ms}$ at the Bokkoya fault zone $(14.2 \mathrm{~m})$, and at the normal NW-SE fault set in the western part of the Bay (Figures 5C, 6).

The throw value obtained between MRS2 (150 kyr) and MRS1 (25 kyr) (Figure 5B) shows that deformation is also distributed throughout the Al Hoceima Bay, but with lower values to the MRS3-MRS2 period (most of them returned values below $11.7 \mathrm{~ms}$, some faults reach up to $12 \mathrm{~ms}, 9.5 \mathrm{~m}$; Figures $5 \mathbf{B}, \mathbf{6}$ ). The maximum values $(23 \mathrm{~ms}, 18.2 \mathrm{~m})$ are clearly focused at the Trougout fault zone (Figures 5B, 6).

The throw value obtained between MRS1 (25 kyr) and the present period (Figure 5A), displays that the relatively high values are concentrated at the Bokkoya fault zone (15 ms maximum, $11.8 \mathrm{~m}$, Figures $\mathbf{5 A}, \mathbf{6}$ ) and the nearby area, and at the 


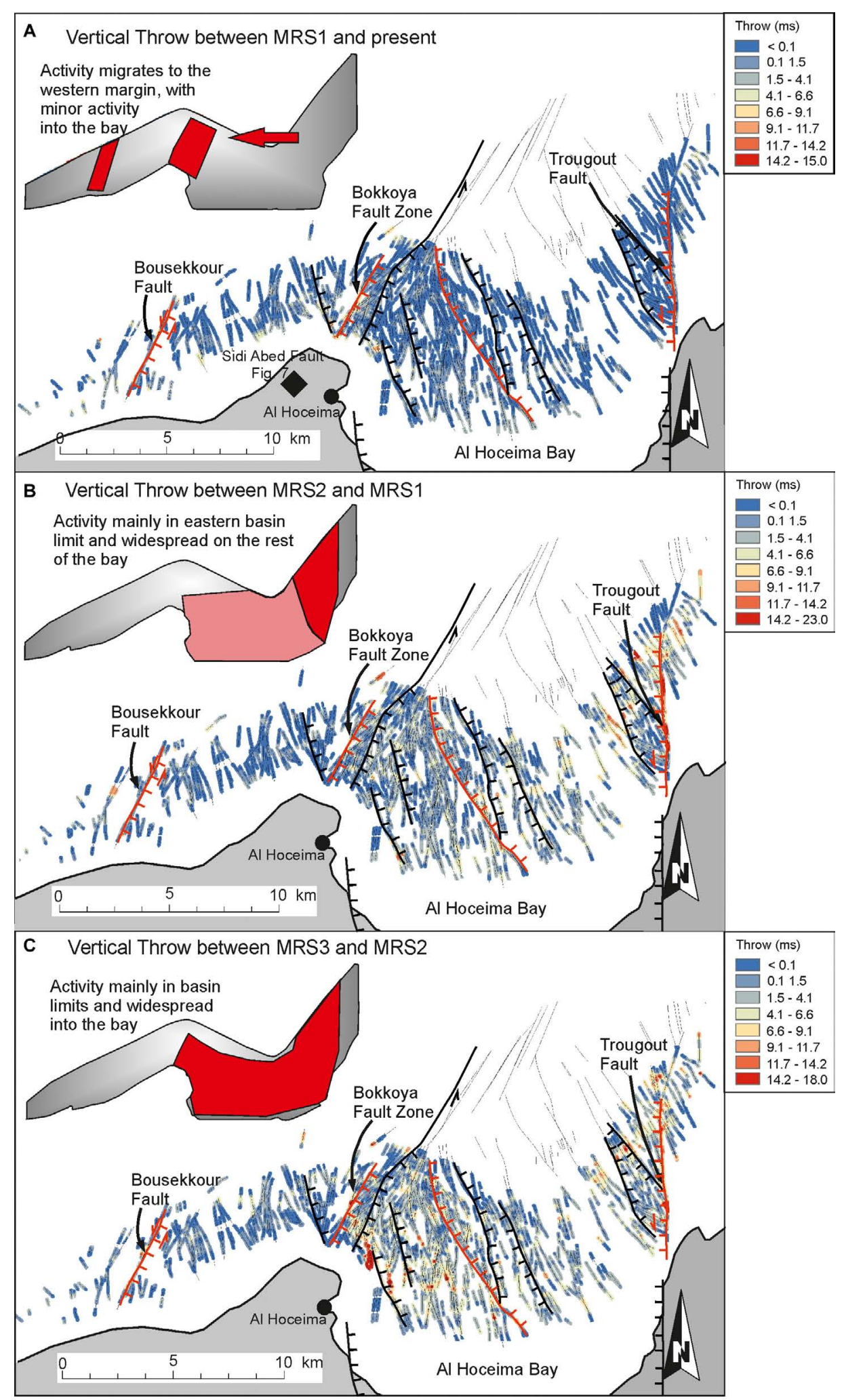

FIGURE 5 | Throw maps in milliseconds (ms), including the traces of faults from Lafosse et al. (2016, 2018). (A) Between MRS1 and present days. (B) Between MRS2 and MRS1. (C) Between MRS3 and MRS2. The maps in the top left corner are outlines of broad areas with major tectonic activity for each period. These areas have been simplified from the detailed throw maps. The main faults traces are also depicted; those in red are the fault traces used for the throw-length profiles of Figure 6 . 

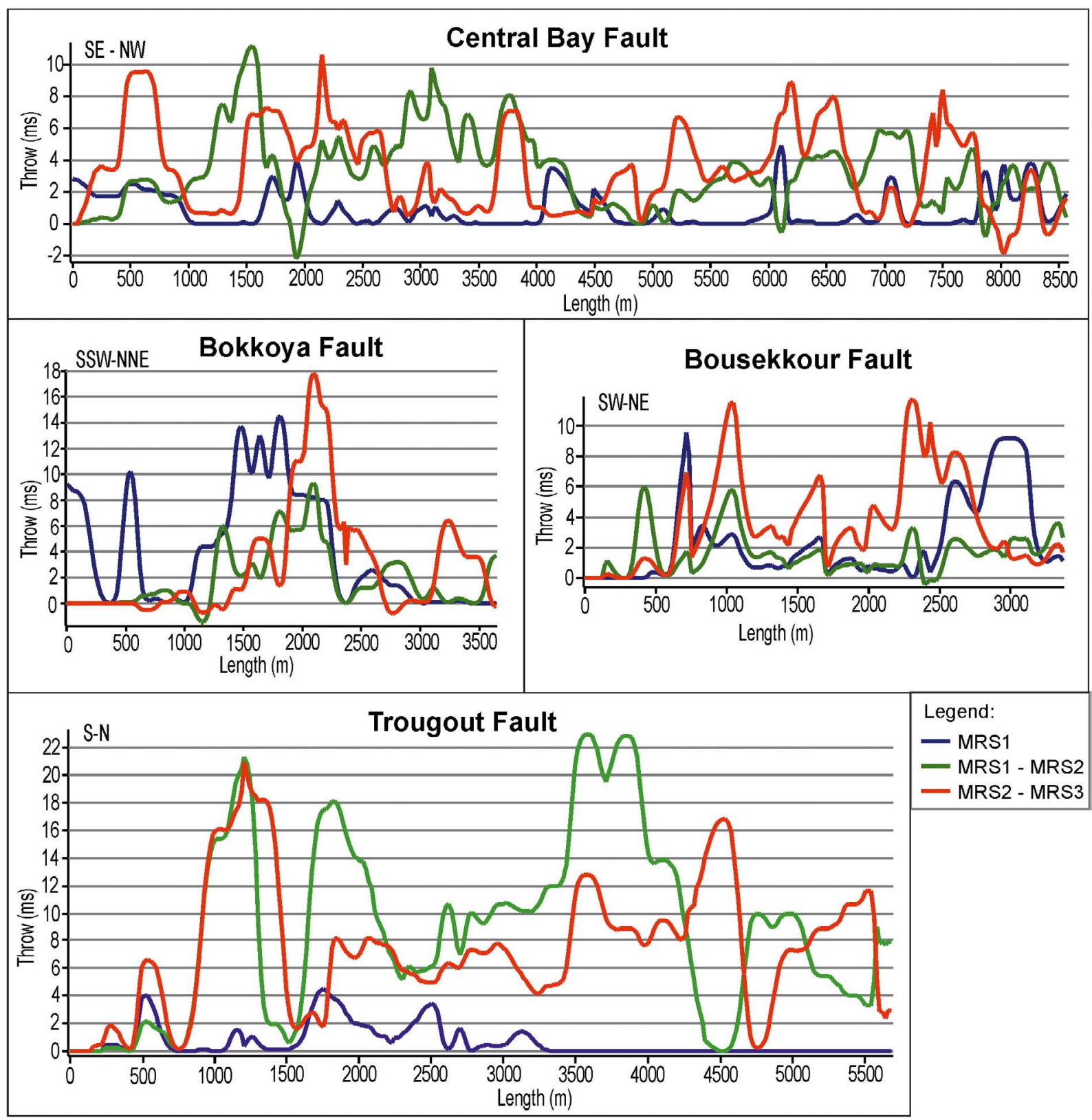

FIGURE 6 | Throw-length profiles obtained from throw maps corresponding to the main faults depicted in Figure 5. Central Bay Fault profile constitutes a representative example of the normal faults located inside the Bay and corresponds to a group of aligned fault traces.

Bousekkour fault zone (close to $10 \mathrm{~ms}, 7.9 \mathrm{~m}$, Figure 6). On the contrary, the Trougout fault zone shows lower values, with only a short segment of the fault still showing tectonic activity $(5 \mathrm{~ms}$, roughly $3.9 \mathrm{~m}$ ) (Figures 5A, 6).

The onshore field study has identified the Sidi Abed fault west of Al Hoceima city, close to the offshore faults (Figures 5A, 7). This fault, which displaces a limestone formation (dorsal complex), has a very high dip $\left(80^{\circ}\right)$, and the fault surface includes dip-slip striations attesting to its normal component. This N-S high angle normal fault is the most outstanding recent deformation recorded onshore (Figure 7). The onshore normal fault of Sidi Abed (Figures 2, 7) can be considered as belonging to the same onshore-offshore fault system that joins the Bokkoya fault zone and the NW-SE normal fault network (Figures 2, 5A, 7c).

\section{Deformation Rate on the Main Fault Zones}

Since the MRS1 to the present period is shorter than the others, the throw rate maps are useful to compare the activity between time periods. Periods, MRS3-MRS2 and MRS2-MRS1 


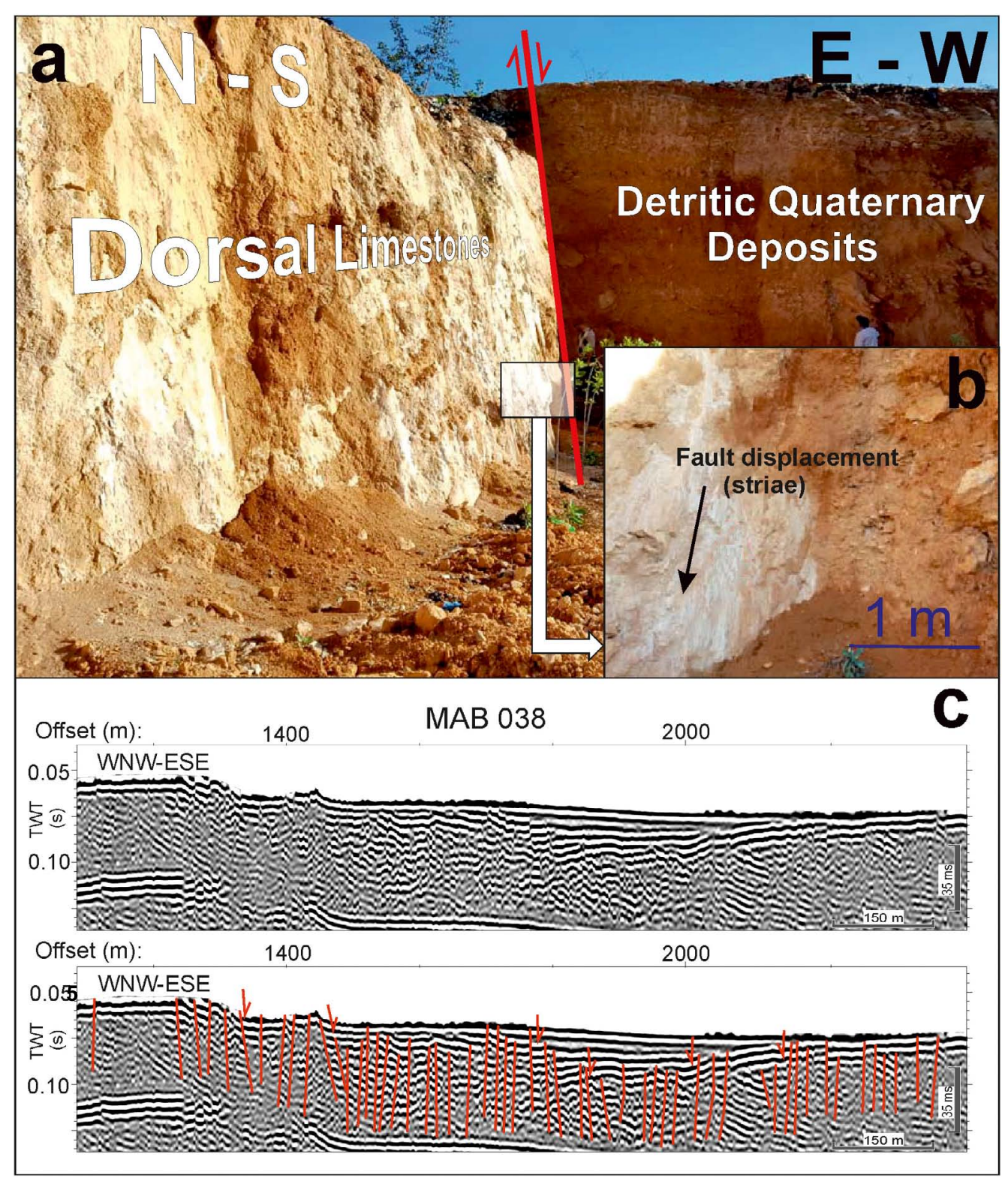

FIGURE 7 | Onshore-offshore link in the Al Hoceima region with the illustration of the onshore Sidi Abed normal fault and the offshore Bokkoya normal faults. (a) Normal fault in the Sidi Abed area that affects the local Quaternary deposits. Fault orientation and dipping are N000 ${ }^{\circ} / 80^{\circ} \mathrm{W}$. (b) Detail of the fault plane; the black arrow marks the orientation and sense of the striae. (c) The uninterpreted and interpreted seismic reflection profile MAB 038 showing normal faults (lines in red) that are associated to the onshore faults of Sidi Abed and the offshore northeast and southwest (NE-SW) Bokkoya normal faults.

are similar; rates of $0.05-0.07 \mathrm{~mm} / \mathrm{year}$ in the faults of the bay, with some peaks close to $0.10 \mathrm{~mm}$ /year in some segments (Figure 8). The Trougout fault shows rates of $0.11 \mathrm{~mm} /$ year in the MRS3-MRS2 period and of $0.15 \mathrm{~mm} /$ year in the MRS2MRS1, where the rates are higher along the whole fault (Figure 8). The Bokkoya fault shows a rate of $0.07 \mathrm{~mm} /$ year at the MRS3-MRS2 period and of $0.06 \mathrm{~mm}$ /year at the MRS2-MRS1 period (Figure 8).

The throw rates of the MRS1 period to the present period contain higher values of throw rate that can go as high as $0.48 \mathrm{~mm} /$ year (Figure 8A). An increase in the values of the
Bokkoya fault is observed as it reaches value of $0.47 \mathrm{~mm} /$ year (Figure 8). In contrast, the Trougout fault shows maximum values of $0.15 \mathrm{~mm} /$ year, which are similar to the previous period.

\section{DISCUSSION}

\section{Migration of Deformation in Al Hoceima Bay}

The positive throw values in Al Hoceima Bay can be interpreted as an indicator of tectonic activity. Some faults in the study 


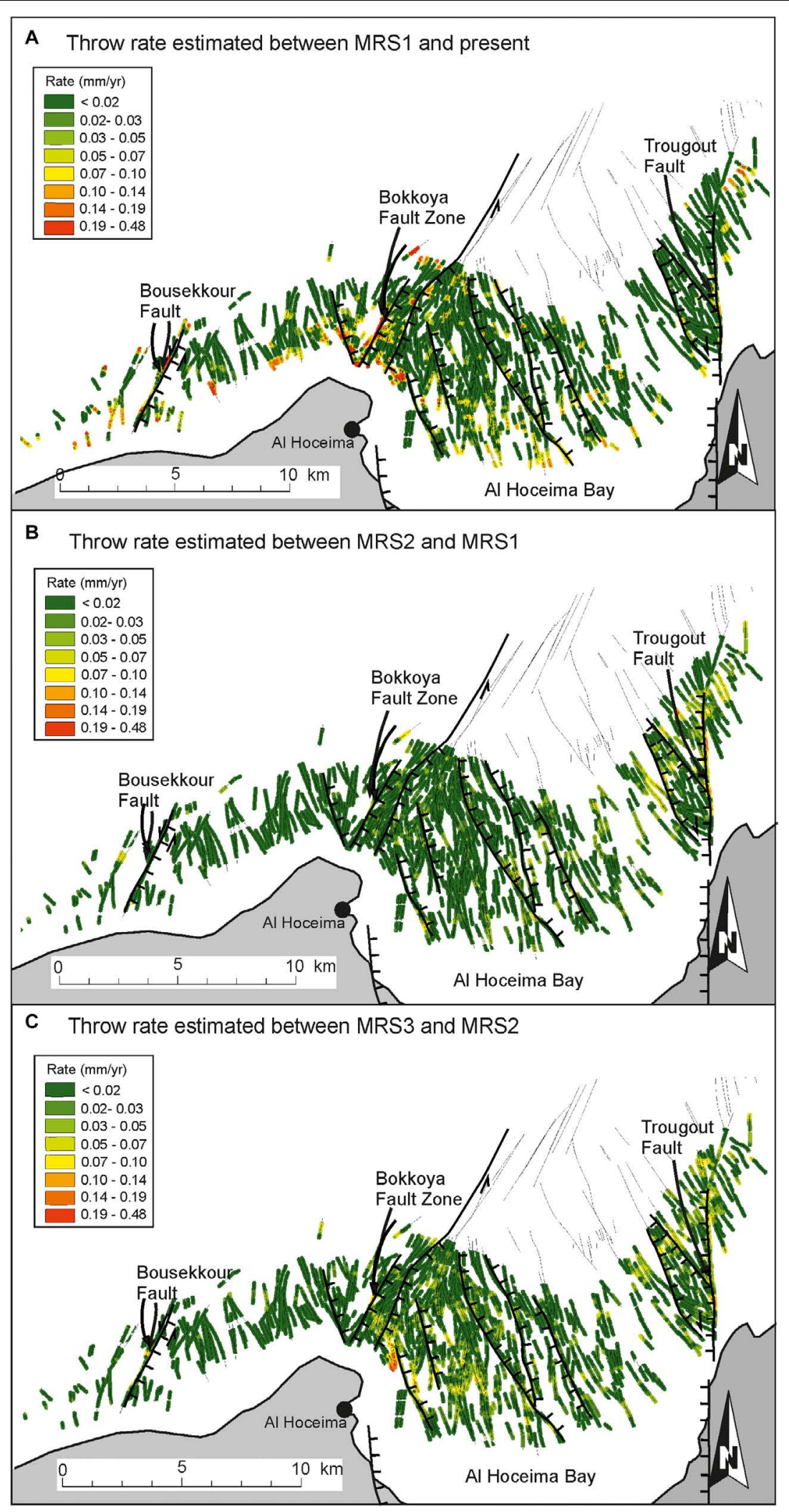

FIGURE 8 | Throw rate maps, including the traces of faults from Lafosse et al. (2016, 2018), with the main faults traces highlighted. (A) Deformation rates between MRS1 and present day. (B) Between MRS2 and MRS1. (C) Between MRS3 and MRS2. Note that the scale of deformation rates between MRS1 and present day is different due to the high values obtained. 
area show mainly strike-slip kinematics (Lafosse et al., 2016), but they have also recorded a vertical throw that reveals their activity. If we consider a roughly constant sedimentary rate during this period, then we may obtain an estimation of the variation of vertical throw rates. In the earliest time windows (MRS3-MRS2, 280-150 kyr, and MRS2-MRS1, 150-25 kyr; Figures 5B,C, 8B,C), the highest vertical throws and slip rates are located in the Nekor basin; in particular, at the N-S Trougout fault and in the north-northwest and southsouthwest (NNW-SSE) faults of the western Al Hoceima Bay. The maximum average throw rates in the fault zones are comprised between 0.10 and $0.15 \mathrm{~mm}$ /year with extreme values reaching up to $0.19 \mathrm{~mm} /$ year. Eastward, the longest synsedimentary NW-SE normal faults in the Al Hoceima Bay also show activity in these periods. The results clearly provide an evidence that during the Middle Pleistocene, the extension through the Al Hoceima Bay was active and distributed between the Bokkoya fault and the Trougout fault. There is a slight regional decrease of the throw values and activity in the MRS2MRS1 period (150-25 kyr), when only the Trougout fault showed throws higher than $7.9 \mathrm{~m}$ (Figure 5B) and some faults in the Bay area.

In contrast, in the youngest period ( $25 \mathrm{kyr}$ to the present), the maximum average throw rates are located along the western margin faults and westward of the Bay (Figures $\mathbf{5 A}, \mathbf{8}$ ). The Trougout fault has very low throw values (Figure 5A). The maximum rates are similar to previous periods $(0.15 \mathrm{~mm} /$ year $)$, but these high values are mainly located in the Bousekkour and Bokkoya fault segments. Although a long recurrence of interval could be considered for the Trougout fault, the decrease in the activity of this fault in the onshore segment was indicated by Poujol et al. (2014) from geochronological data, where a return period of $3.1 \mathrm{kyr}$ is proposed. This estimation makes us consider that a period of $25 \mathrm{kyr}$ is enough to study the fault activity evolution. Moreover, the absence of recent continuous fault scarps onshore (Galindo-Zaldivar et al., 2009) and of the sediments that overlap the fault offshore (Figure 3, Profile 84) suggests a very recent inactivation of the structure, which may remain with a residual activity. Unlike the Trougout fault, the Bokkoya fault reaches the highest throw rate values in the most recent period $(0.48 \mathrm{~mm} /$ year $)$ which indicates a clear acceleration with respect to the previous periods (maximum of $0.06 \mathrm{~mm} /$ year) and that deformation is focused in this structure. Similar behavior is observed in the Bousekkour fault with previous rates of up to $0.10 \mathrm{~mm} /$ year and the most recent rates of $0.33 \mathrm{~mm} /$ year. This suggests an acceleration of the deformation speed in these faults. In fact, if we consider a general overestimation of throw rates at the MRS1-present period due to the high slope of the MRS1 related to the margins and sedimentary processes, the throw rate of the Trougout fault would be lower than in the previous period. On the other hand, by taking into account of the possible overestimation, a change from 0.07 to 0.48 would imply an acceleration of the deformation rate in the Bokkoya fault zone. This deformation could be related to recent coseismic deformation, since the western area of the Bay is where the seismicity is concentrated (Figure 2).
These results show that the fault activity during the Late Pleistocene has increased and migrated westward in the $\mathrm{Al}$ Hoceima Bay. The sum of the data presented indicates an evolution from an initial stage of distributed transtensional extension affecting the whole Bay to a localized deformation stage characterized by a concentrated fault activity in the westward part of the Bay, and in the Bokkoya and Bousekkour faults. This activity is also simultaneous to a progressive inactivation of the Eastern Bay faults, including the Trougout fault.

The westward migration implies that the most active faults are now closer to the most populated areas nearby Al Hoceima, and thus have strong implications in terms of hazard assessment. Some of the faults that are very close to Al Hoceima port may have tsunamigenic effects during coseismic deformation events and may have incidence in this infrastructure.

Westward migration of shallow deformation is in coherence with the major earthquake epicenter locations westward of the Al-Idrissi and Trougout fault zones, under the Bokkoya Massif and Bokkoya fault zones (Figure 2; El Alami et al., 1998; Stich et al., 2005; Galindo-Zaldivar et al., 2009, 2018; Van der Woerd et al., 2014). Onshore, the activity of recent normal faults has been only clearly observed from the Sidi Abed to the coastal area of Sabadia Beach (Figures 2, 7), suggesting that the most recent offshore fault activity is in clear continuity with the onshore faulting and seismicity near Al Hoceima (Figure 2). The Sidi Abed fault provides the best opportunity to have a direct observation of fault features that belong to the same fault system as that of the offshore faults. It is also remarkable that the very high dip value $\left(80^{\circ}\right)$ of the Sidi Abed fault surface showed dip-slip striations instead of just strikeslip ones, as would be expected according to focal mechanisms of the area of the earthquake (Figures 2, 7). Similar faults have been observed in Campo de Dalias, north of Alboran Sea (Marín-Lechado et al., 2004), and are the result of fault reactivation of early extensional hybrid or strike-slip joints characterized by vertical fracture surfaces that are reactivated as extensional faults during the most recent extensional stage. Another zone with a similar evolution and propagation of its faulting pattern is located in the Taranaki Basin and the Taupo Rift (New Zealand) (Giba et al., 2010, 2012, 2013; Seebeck et al., 2014).

\section{Local Deformation Into the Westernmost Mediterranean Geodynamics}

The Al Hoceima Bay is located at a key area of the plate boundary affected simultaneously by the tectonic indentation in the central Alboran Sea and the subducted slab delamination processes related with the westward migration of the Gibraltar Arc (Figure 9). The deformation of recent deposits constitutes an opportunity to improve the knowledge on the evolution of deformation in this plate boundary.

The rigid South Alboran Block (Figure 9b) attached to the African Plate moves NW causing indentation in the Alboran Domain (Estrada et al., 2018). The western limit of the South Alboran Block is the left lateral Al Idrissi fault zone, formed by the former Al Idrissi fault (Gràcia et al., 2019) and new faults that 


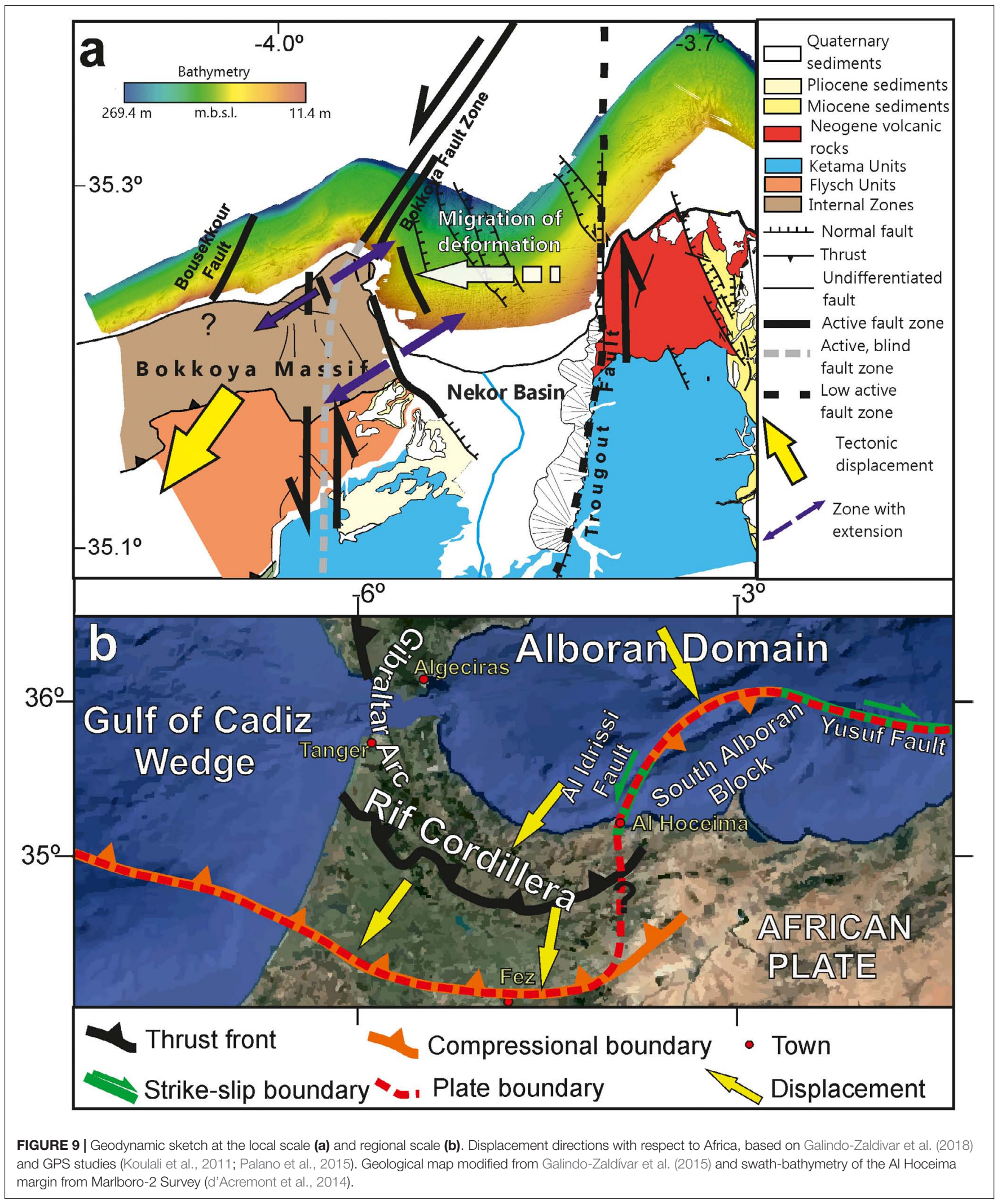


develop westward (Galindo-Zaldivar et al., 2018). This fault zone extends toward the NW-SE normal fault splay in the Al Hoceima Bay (Lafosse et al., 2020) and produced the Nekor transtensional basin (d'Acremont et al., 2014) facilitating the southwestward motion of the Rif (Figure 9). The Bokkoya Massif, which belongs to the Rif, underwent east-northeast and west-southwest (ENE-WSW) extension and a westward displacement with respect to Africa (Figure 9). The westward migration of the tectonic activity has already been proposed for the whole region and for the Gibraltar Arc (Figure 9; e.g., Galindo-Zaldivar et al., 2009, 2018; Koulali et al., 2011; d'Acremont et al., 2014; Palano et al., 2015). The driving mechanism responsible for this migration is still being discussed. Most proposals consider mantle delamination (e.g., Seber et al., 1996; Mancilla et al., 2013; Petit et al., 2015; Hidas et al., 2019) or subduction with or without slab roll-back (e.g., Blanco and Spakman, 1993; Ruiz-Constán et al., 2011; González-Castillo et al., 2015; Do Couto et al., 2016; Spakman et al., 2018). GPS studies (Koulali et al., 2011; Palano et al., 2015) show a southward movement of the Rif Cordillera, possibly due to the drag of a subducted slab according to mantle tomographies (e.g., Faccena et al., 2014 and references therein) or subduction following mantle delamination (Baratin et al., 2016). For the first time, this work demonstrated that the westward migration of the deformation can also be observed in the shallow sedimentary record at a local scale. However, the development of the fault systems as part of a transtensional basin related with the Al Idrissi fault zone southern termination as a horsetail splay (d'Acremont et al., 2014; Lafosse et al., 2020) does not fully justify this westward migration. The continuous Al Idrissi fault zone activity may increase the brittle deformation at the fault tip and the enlargement of the $\mathrm{Al}$ Hoceima Bay system, but it does not explain why the eastern faults decrease their activity while the western ones increase it. In order to fully support this migration model, other regional processes need to be taken into account. For the purpose of this paper, the progressive inactivation of the Trougout (relayed over by western faults) and Eastern Bay faults is proposed to be an indication of the NW movement of the South Alboran indenter, as described byEstrada et al. (2018), interacting with the deformation of the Rif that moves toward the SW (Figure 9).

Overall, our results fit with the proposal of Fadil et al. (2006) that suggested that the central Alboran Sea and the Rif front should represent two segments of the AfricaEurasia collisional plate boundary zone in the westernmost Mediterranean. These compressional boundaries are linked by the Al-Idrissi-Bokkoya left lateral fault system and continue eastward through the right lateral Yusuf fault system (Figure 9). This hypothesis is in coherence with crustal velocity models which show a strong thinning of the crust in the Nekor Basin (e.g., Koulali et al., 2011; Palano et al., 2015) in a setting with NW-SE compression and orthogonal NESW extension (e.g., Stich et al., 2005, 2006; Neres et al., 2016).

This automation of throw backstripping has been successful in the analysis of a large number of syn-sedimentary faults occurred in the Al Hoceima Bay at the same time, and provided throw maps in a zone densely faulted, so that the migration of the activity inside the system can be seen without analyzing fault by fault. It may also be applied to growth fault systems like that of the Gulf of Mexico (Worrall and Snelson, 1989), Eastern Mediterranean (Baudon and Cartwright, 2008), or Niger Delta (Back et al., 2006). The method could also be useful in transtensional fault zones like the Southern Dead Sea Fault (Smit et al., 2010) and the western tip of EnriquilloPlantain Garden Fault Zone in Haiti (Leroy et al., 2015), and may improve the analysis of major changes in the style of deformation of complex regions like the Aegean (Sakellariou and Tsampouraki-Kraounaki, 2019).

\section{CONCLUSION}

Faulting throw analysis in the $\mathrm{Al}$ Hoceima Bay reveals a westward increase and migration of the deformation. The automation of the throw backstripping method applied on 672 faults has resulted to be an effective and a quick tool to decipher the distribution of tectonic activity during the last $280 \mathrm{kyr}$, considering the deformation of the recent and widespread MRS by high dipping faults. The detailed analysis of the fault throws, their distribution through time, and their quantification was achieved for the first time in the zone, which demonstrates a westward increase and migration of the deformation toward the western part of the Al Hoceima Bay and offshore Bokkoya Massif. Our data indicate the present day highest deformation rate in the faults next to the most populated city, Al Hoceima, reaching the values of throw up to $0.47 \mathrm{~mm} /$ year. Therefore, this automation of the throw backstripping method may be adopted as a basis for reliable and accurate seismic (and potential tsunami) hazard assessments by detecting the zones where further and detailed studies should be carried out.

The westward migration of deformation in the Al Hoceima Bay is framed into the westernmost Mediterranean geodynamic model, and it may be the result of the interaction between the NW movement of the South Alboran indenter and the back Rif south-westward displacement due to subduction with roll-back, the sinking of the subducted continental slab, or mantle delamination.

The automation of the throw backstripping may also be applied to growth fault systems in similar contexts of the eastern Mediterranean and western Atlantic in the Gulf of Mexico and Caribbean Sea. The high accuracy degree in constraining the timing and rate of fault activity will contribute to improve the seismic hazard assessment.

\section{DATA AVAILABILITY STATEMENT}

The raw data supporting the conclusions of this article will be made available by the authors, without undue reservation. 


\section{AUTHOR CONTRIBUTIONS}

All authors listed have made a substantial, direct and intellectual contribution to the work, and approved it for publication.

\section{FUNDING}

This study was supported by projects CGL2016-80687-R AEI/FEDER, P18-RT-3275, B-RNM-301-UGR18 and RNM148 (Junta de Andalucía/FEDER); ALBAMAR JCJC ANR-17-CE030004; the EUROFLEETS program (FP7/2007-2013; n²28344);

\section{REFERENCES}

Aït Brahim, L., and Chotin, P. (1990). Oriental Moroccan Neogene volcanism and strike-slip faulting. J. Afr. Earth Sci. 11, 273-280.

Andrieux, J. (1971). La structure du Rif Central. Étude des relations entre la tectonique de compression et les nappes de glissement dans un tronçon de la chaîne alpine. Ed. Notes et Mém. Serv. Géol. Maroc. 235, 1-155.

Azdimousa, A., Bourgois, J., Poupeau, G., and Montigny, R. (1998). Histoire thermique du massif de Ketama (Maroc): sa place en Afrique du Nord et dans les Cordilleres Betiques. C. R. Acad. Sci. 326, 847-853.

Back, S., Höcker, C., Brundiers, M. B., and Kukla, P. A. (2006). Three-dimensionalseismic coherency signature of Niger Delta growth faults: integrating sedimentology and tectonics. Basin Res. 18, 323-337.

Balanyá, J. C., Crespo-Blanc, A., Díaz Azpiroz, M., Expósito, I., and Luján, M. (2007). Structural trend line pattern and strain partitioning around the Gibraltar Arc accretionary wedge: insights as to the mode of orogenic arc building. Tectonics 26:TC2005. doi: 10.1029/2005TC001932

Baratin, L. M., Mazzotti, S., Chéry, J., Vernant, P., Tahayt, A., and Mourabit, T. (2016). Incipient mantle delamination, active tectonics and crustal thickening in Northern Morocco: insights from gravity data and numerical modelling. Earth Planet. Sci. Lett. 454, 113-120.

Baudon, C., and Cartwright, J. (2008). Early stage evolution of growth faults: 3D seismic insights from the Levant Basin, Eastern Mediterranean. J. Struct. Geol. 30, 888-898.

Biggs, J., Bergman, E., Emmerson, B., Funning, G. J., Jackson, J., Parsons, B., et al. (2006). Fault identification for buried strike-slip earthquakes using InSAR: the 1994 and $2004 \mathrm{Al}$ Hoceima, Morocco earthquakes. Geophys. J. Int. 166, 1347-1362. doi: 10.1111/j.1365-246X.2006.03071.x

Blanco, M. J., and Spakman, W. (1993). The P-wave velocity structure of the mantle below the Iberian Peninsula: evidence for subducted lithosphere below southern spain. Tectonophysics 221, 13-34. doi: 10.1016/0040-1951(93)90025-F

Calvert, A., Gomez, F., Seber, D., Barazangi, M., Jabour, N., Ibenbrahim, A., et al. (1997). An integrated geophysical investigation of recent seismicity in the Al-Hoceima region of North Morocco. Bull. Seismol. Soc. Am. 87, 637-651.

Carrapa, B. (2009). Tracing exhumation and orogenic wedge dynamics in the European Alps with detrital thermochronology. Geology 37, 1127-1130.

Cartwright, J., Bouroullec, R., James, D., and Johnson, H. (1998). Polycyclic motion history of some Gulf Coast growth faults from high-resolution displacement analysis. Geology 26, 819-822.

Carver, R. E. (1968). Differential compaction as a cause of regional contemporaneous faults. Am. Assoc. Petrol. Geol. Bull. 52, 414-419.

Chalouan, A. (1986). Les Nappes Ghomarides (Rif Septentrional, Maroc), un Terrain Varisque Dans la Chaine Alpine. Doctoral thesis, Université Louis Pasteur, Strasbourg.

Chalouan, A., Michard, A., Kadiri, K., Negro, F., Lamotte, D., Soto, J. I., et al. (2008). "The Rif belt," in Continental Evolution. The Geology of Morocco, eds A. Michard, O. Saddiqi, A. Chalouan, and D. Frizon de Lamotte (Berlin: Springer), 203-302.

Childs, C., Easton, S. J., Vendeville, B. C., Jackson, M. P. A., Lin, S. T., Walsh, J. J., et al. (1993). Kinematic analysis of faults in a physical model of growth faulting above a viscous salt analogue. Tectonophysics 228, 313-329. project FICTS-2011-03-01; and the FPU PhD grant (16/04038), and also by the Spanish Government through the 'Severo Ochoa Centre of Excellence' accreditation (CEX2019-000928-S).

\section{ACKNOWLEDGMENTS}

The IHS KINGDOM software package was utilized in the present study. We also to the marine surveys, MARLBORO2 and SARAS (https://campagnes.flotteoceanographique.fr/ campagnes/12450090/; https://campagnes.flotteoceanographique. $\mathrm{fr} /$ campagnes/12000010/).

Childs, C., Watterson, J., and Walsh, J. J. (1995). Fault overlap zones within developing normal fault systems. J. Geol. Soc. 152, 535-549. doi: 10.1144/gsigs. 152.3.0535

Comas, M., García-Dueñas, V., and Jurado, M. (1992). Neogene tectonic evolution of the Alboran Sea from MCS data. Geo Mar. Lett. 12, 157-164. doi: 10.1007/ BF02084927

Cornell, C. A. (1968). Engineering seismic risk analysis. Bull. Seismol. Soc. Am. 58, 1583-1606.

Corsini, M., Chalouan, A., and Galindo-Zaldivar, J. (2014). Geodynamics of the Gibraltar Arc and the Alboran Sea region. J. Geodyn. 77, 1-3. doi: 10.1016/j.jog. 2014.04.005

d'Acremont, E., Gutscher, M. A., Rabaute, A., Mercier de Lépinay, B., Lafosse, M., Poort, J., et al. (2014). High-resolution imagery of active faulting offshore Al Hoceima, Northern Morocco. Tectonophysics 632, 160-166. doi: 10.1016/j. tecto.2014.06.008

d'Acremont, E., Lafosse, M., Rabaute, A., Teurquety, G., Do Couto, D., Ercilla, G., et al. (2020). Polyphase tectonic evolution of fore-arc basin related to STEP fault as revealed by seismic reflection data from the Alboran Sea (W-Mediterranean). Tectonics 39:e2019TC005885. doi: 10.1029/2019TC005885

Davis, D., Suppe, J., and Dahlen, F. A. (1983). Mechanics of fold-and-thrust belts and accretionary wedges. J. Geophys. Res. Solid Earth 88, 1153-1172.

De Larouzière, F. D., Bolze, J., Bordet, P., Hernandez, J., Montenat, C., and d'Estevou, P. O. (1988). The Betic segment of the lithospheric Trans-Alboran shear zone during the Late Miocene. Tectonophysics 152, 41-52. doi: 10.1016/ 0040-1951(88)90028-5

DeMets, C., Gordon, R. G., and Argus, D. F. (2010). Geologically current plate motions. Geophys. J. Int. 181, 1-80. doi: 10.1111/j.1365-246X.2009.04491.x

Do Couto, D., Gorini, C., Jolivet, L., Lebret, N., Augier, R., Gumiaux, C., et al. (2016). Tectonic and stratigraphic evolution of the Western Alboran Sea Basin in the last 25 Myrs. Tectonophysics 667-668, 208-311. doi: 10.1016/j.tecto.2016. 03.020

El Alami, S. O., Tadili, B. A., Cherkaoui, T. E., Medina, F., Ramdani, M., Brahim, L. A., et al. (1998). The Al Hoceima Earthquake of May 26, 1994 and its aftershocks: a seismotectonic study. Anali di Geofisica 41, 519-537.

El Azzouzi, M., Bernard-Griffiths, J., Bellon, H., Maury, R. C., Pique, A., Fourcade, S., et al. (1999). Evolution des sources du volcanisme marocain au cours du Neogene. C. R. Acad. Sci. 329, 95-102.

Estrada, F., Galindo-Zaldivar, J., Vázquez, J. T., Ercilla, G., D’Acremont, E., Alonso, B., et al. (2018). Tectonic indentation in the central Alboran Sea (westernmost Mediterranean). Terra Nova 30, 24-33. doi: 10.1111/ter.12304

Faccena, C., Becker, T. W., Auer, L., Billi, A., Boschi, L., Brun, J. P., et al. (2014). Mantle dynamics in the Mediterranean. Rev. Gephys. 52, 283-332. doi: 10.1002/ 2013RG000444

Fadil, A., Vernant, P., McClusky, S., Reilinger, R., Gomez, F., Sari, D. B., et al. (2006). Active tectonics of the western Mediterranean: geodetic evidence for rollback of a delaminated subcontinental lithospheric slab beneath the Rif Mountains, Morocco. Geology 34, 529-532. doi: 10.1130/G22291.1

Frigola, J., Canals, M., Cacho, I., Moreno Caballud, A., Sierro, F. J., Flores, J. A., et al. (2012). A $500 \mathrm{kyr}$ record of global sea level oscillations in the Gulf of Lion, Mediterranean Sea: new insights into MIS 3 sea level variability. Clim. Past 8, 1067-1077. doi: 10.5194/cp-8-1067-2012 
Frizon de Lamotte, D. (1985). La structure du Rif Oriental (Maroc). Rôle de la Tectonique Longitudinale et Importance des Fluides. Doctoral thesis, Université Pierre et Marie Curie, Paris.

Galadini, F., and Messina, P. (2004). Early-Middle Pleistocene eastward migration of the Abruzzi Apennine (central Italy) extensional domain. J. Geodyn. 37, 57-81.

Galindo-Zaldívar, J., Azzouz, O., Chalouan, A., Pedrera, A., Ruano, P., RuizConstán, A., et al. (2015). Extensional tectonics, graben development and fault terminations in the eastern Rif (Bokoya-Ras Afraou area). Tectonophysics 663, 140-149. doi: 10.1016/j.tecto.2015.08.029

Galindo-Zaldivar, J., Chalouan, A., Azzouz, O., Sanz de Galdeano, C., Anahnah, F., Ameza, L., et al. (2009). Are the seismological and geological observations of the Al Hoceima (Morocco, Rif) 2004 earthquake $(\mathrm{M}=6.3)$ contradictory? Tectonophysics 475, 59-67.

Galindo-Zaldivar, J., Ercilla, G., Estrada, F., Catalán, M., d’Acremont, E., Azzouz, O., et al. (2018). Imaging the growth of recent faults: The case of 20162017 seismic sequence sea bottom deformation in the Alboran Sea (western Mediterranean). Tectonics 37, 2513-2530. doi: 10.1029/2017TC004941

García-Dueñas, V., Balanyá, J. C., and Martínez-Martínez, J. M. (1992). Miocene extensional detachments in the outcropping basement of the Northern Alboran Basin (Betics) and their tectonic implications. Geo Mar. Lett. 12, 88-95.

Giba, M., Nicol, A., and Walsh, J. J. (2010). Evolution of faulting and volcanism in a back-arc basin and its implications for subduction processes. Tectonics 29:TC4020.

Giba, M., Walsh, J. J., and Nicol, A. (2012). Segmentation and growth of an obliquely reactivated normal fault. J. Struct. Geol. 39, 253-267.

Giba, M., Walsh, J. J., Nicol, A., Mouslopoulou, V., and Seebeck, H. (2013). Investigation of the spatio-temporal relationship between normal faulting and arc volcanism on million-year time scales. J. Geol. Soc. 170, 951-962.

Goldsworthy, M., and Jackson, J. (2001). Migration of activity within normal fault systems: examples from the Quaternary of mainland Greece. J. Struct. Geol. 23, 489-506.

Gomez de la Pena, L., Ranero, C. R., and Gràcia, E. (2018). The crustal domains of the Alboran Basin (western Mediterranean). Tectonics 37, 3352-3377.

González-Castillo, L., Galindo-Zaldivar, J., de Lacy, M. C., Borque, M. J., MartinezMoreno, F. J., García-Armenteros, J. A., et al. (2015). Active rollback in the Gibraltar Arc: evidences from CGPS data in the western Betic Cordillera. Tectonophysics 663, 310-321.

Gràcia, E., Grevemeyer, I., Bartolomé, R., Perea, H., Martínez-Loriente, S., de la Peña, L. G., et al. (2019). Earthquake crisis unveils the growth of an incipient continental fault system. Nat. Commun. 10:3482.

Grant, K. M., Rohling, E. J., Ramsey, C. B., Cheng, H., Edwards, R. L., Florindo, F., et al. (2014). Sea-level variability over five glacial cycles. Nat. Commun. 5, 1-9.

Hidas, K., Garrido, C. J., Booth-Rea, G., Marchesi, C., Bodinier, J. L., Dautria, J. M., et al. (2019). Lithosphere tearing along STEP faults and synkinematic formation of lherzolite and wehrlite in the shallow subcontinental mantle. Solid Earth 10, 1099-1121. doi: 10.5194/se-10-1099-2019

Jackson, C. A.-L., Bell, R. E., Rotevatn, A., and Tvedt, A. B. M. (2017). Techniques to determine the kinematics of synsedimentary normal faults and implications for fault growth models. Geol. Soc. Lond. 439, 187-217. doi: 10.1144/SP439.22

Juan, C., Ercilla, G., Hernández-Molina, J. F., Estrada, F., Alonso, B., Casas, D., et al. (2016). Seismic evidence of current-controlled sedimentation in the Alboran Sea during the Pliocene and Quaternary: Palaeoceanographic implications. Mar. Geol. 378, 292-311. doi: 10.1016/j.margeo.2016.01.006

Keller, E. A., and Pinter, N. (1996). Active Tectonics, Vol. 19. Upper Saddle River, NJ: Prentice Hall.

Koulali, A., Ouazar, D., Tahayt, A., King, R. W., Vernant, P., Reilinger, R. E., et al. (2011). New GPS constraints on active deformation along the Africa-Iberia plate boundary. Earth Planet. Sci. Lett. 308, 211-217.

Lafosse, M., d'Acremont, E., Rabaute, A., Estrada, F., Jollivet-Castelot, M., Vazquez, J. T., et al. (2020). Plio-Quaternary tectonic evolution of the southern margin of the Alboran Basin (Western Mediterranean). Solid Earth 11, 741-765. doi: 10.5194/se-11-741-2020

Lafosse, M., d'Acremont, E., Rabaute, A., Mercier de Lépinay, B., Tahayt, A., Ammar, A., et al. (2016). Evidence of Quaternary transtensional tectonics in the Nekor basin (NE Morocco). Basin Res. 29, 470-489. doi: 10.1111/bre.12185

Lafosse, M., Gorini, C., Le Roy, P., Alonso, B., d'Acremont, E., Ercilla, G., et al. (2018). Late Pleistocene-Holocene history of a tectonically active segment of the continental margin (Nekor basin, Western Mediterranean, Morocco). Mar. Petrol. Geol. 97, 370-389. doi: 10.1016/j.marpetgeo.2018.07.022

Leblanc, D., and Olivier, P. (1984). Role of strike-slip faults in the Betic-Rifian orogeny. Tectonophysics 101, 345-355.

Leroy, S., Ellouz-Zimmermann, N., Corbeau, J., Rolandone, F., de Lepinay, B. M., Meyer, B., et al. (2015). Segmentation and kinematics of the North AmericaCaribbean plate boundary offshore Hispaniola. Terra Nova 27, 467-478. doi: 10.1111/ter.12181

Mancilla, F. D. L., Stich, D., Berrocoso, M., Martín, R., Morales, J., Fernandez-Ros, A., et al. (2013). Delamination in the Betic range: deep structure, seismicity, and GPS motion. Geology 41, 307-310. doi: 10.1130/G33733.1

Mansfield, C. S., and Cartwright, J. A. (1996). High resolution displacement mapping from 3-D seismic data. J. Struct. Geol. 18, 249-263.

Marín-Lechado, C., Galindo-Zaldívar, J., Rodríguez-Fernández, L. R., and González-Lodeiro, F. (2004). Faulted hybrid joints: an example from the Campo de Dalias (Betic Cordilleras, Spain). J. Struct. Geol. 26, 2025-2037.

Martínez-García, P., Comas, M., Lonergan, L., and Watts, A. B. (2017). From extension to shortening: tectonic inversion distributed in time and space in the Alboran Sea, western Mediterranean. Tectonics 36, 2777-2805. doi: 10.1002/ 2017TC004489

Martínez-García, P., Comas, M., Soto, J. I, Lonergan, L., and Watts, A. B. (2013). Strike-slip tectonics and basin inversion in the Western Mediterranean: the Post-Messinian evolution of the Alboran Sea. Basin Res. 25, 361-387.

McCalpin, J. P. (2009). Paleoseismology. Cambridge, MA: Academic Press.

Meyer, V., Nicol, A., Childs, C., Walsh, J. J., and Watterson, J. (2002). Progressive localisation of strain during the evolution of a normal fault population. J. Struct. Geol. 24, 1215-1231.

Milia, A., and Torrente, M. M. (2018). Extensional Messinian basins in the Central Mediterranean (Calabria, Italy): new stratigraphic and tectonic insights. Oil Gas Sci. Technol. 73:45. doi: 10.2516/ogst/2018040

Neres, M., Carafa, M. M. C., Fernandes, R. M. S., Matias, L., Duarte, J. C., Barba, S., et al. (2016). Lithospheric deformation in the Africa-Iberia plate boundary: improved neotectonic modeling testing a basal-driven Alboran plate. J. Geophys. Res. Solid Earth 121, 6566-6596. doi: 10.1002/2016JB01 3012

Nicol, A., Walsh, J., Berryman, K., and Nodder, S. (2005). Growth of a normal fault by the accumulation of slip over millions of years. J. Struct. Geol. 27, 327-342.

Nicol, A., Walsh, J., Berryman, K., and Villamor, P. (2006). Interdependence of fault displacement rates and paleoearthquakes in an active rift. Geology 34, 865-868.

Nicol, A., Walsh, J. J., Watterson, J., and Underhill, J. R. (1997). Displacement rates of normal faults. Nature 390, 157-159.

Palano, M., González, P. J., and Fernández, J. (2015). The Diffuse Plate boundary of Nubia and Iberia in the Western Mediterranean: Crustal deformation evidence for viscous coupling and fragmented lithosphere. Earth Planet. Sci. Lett. 430, 439-447. doi: 10.1016/j.epsl.2015.08.040

Perea, H., Gràcia, E., Martínez-Loriente, S., Bartolome, R., de la Peña, L. G., de Mol, B., et al. (2018). Kinematic analysis of secondary faults within a distributed shear-zone reveals fault linkage and increased seismic hazard. Mar. Geol. 399, 23-33.

Petersen, K., Clausen, O. R., and Korstgård, J. A. (1992). Evolution of a salt-related listric growth fault near the D-1 well, block 5605, Danish North Sea: displacement history and salt kinematics. J. Struct. Geol. 14, 565-577.

Petit, C., Le Pourhiet, L., Scalabrino, B., Corsini, M., Bonnin, M., and Romagny, A. (2015). Crustal structure and gravity anomalies beneath the Rif, northern Morocco: implications for the current tectonics of the Alboran region. Geophys. J. Int. 202, 640-652. doi: 10.1093/gji/ggv169

Phillips, T. B., Jackson, C. A. L., Bell, R. E., and Duffy, O. B. (2018). Oblique reactivation of lithosphere-scale lineaments controls rift physiography - the upper-crustal expression of the Sorgenfrei-Tornquist Zone, offshore southern Norway. Solid Earth 9, 403-429. doi: 10.5194/se-9-403-2018

Poujol, A., Ritz, J. F., Tahayt, A., Vernant, P., Condomines, M., Blard, P. H., et al. (2014). Active tectonics of the Northern Rif (Morocco) from geomorphic and geochronological data. J. Geodyn. 77, 70-88.

Ruiz-Constán, A., Galindo-Zaldivar, J., Pedrera, A., Célérier, B., and MarínLechado, C. (2011). Stress distribution at the transition from subduction to continental collision (northwestern and central Betic Cordillera). Geochem. Geophys. Geosyst. 12:Q12002. doi: 10.1029/2011GC003824 
Sakellariou, D., and Tsampouraki-Kraounaki, K. (2019). "Plio-Quaternary extension and strike-slip tectonics in the Aegean," in Transform Plate Boundaries and Fracture Zones, ed. J. C. Duarte (Amsterdam: Elsevier), 339374. doi: 10.1016/B978-0-12-812064-4.00014-1

Sanz de Galdeano, C., and Alfaro, P. (2004). Tectonic significance of the present relief of the Betic Cordillera. Geomorphology 63, 175-190. doi: 10.1016/j. geomorph.2004.04.002

Seber, D., Barazangi, M., Ibenbrahim, A., and Demnati, A. (1996). Geophysical evidence for lithospheric delamination beneath the Alboran Sea and Rif-Betic mountains. Nature 379, 785-790.

Seebeck, H., Nicol, A., Villamor, P., Ristau, J., and Pettinga, J. (2014). Structure and kinematics of the Taupo Rift, New Zealand. Tectonics 33, 1178-1199.

Smit, J., Brun, J. P., Cloetingh, S., and Ben-Avraham, Z. (2010). The rift-like structure and asymmetry of the Dead Sea Fault. Earth Planet. Sci. Lett. 290, 74-82. doi: 10.1016/j.epsl.2009.11.060

Spakman, W., Chertova, M. V., van den Berg, A., and van Hinsbergen, D. J. (2018). Puzzling features of western Mediterranean tectonics explained by slab dragging. Nat. Geosci. 11, 211-216. doi: 10.1038/s41561-018-0066-z

Stich, D., Mancilla, F., Baumont, D., and Morales, J. (2005). Source analysis of the Mw 6.32004 Al Hoceima Earthquake (Morocco) using regional apparent source time functions. J. Geophys. Res. 110:B06306. doi: 10.1029/2004JB00 3366

Stich, D., Serpelloni, E., Mancilla, F., and Morales, J. (2006). Kinematics of the Iberia-Maghreb plate contact from seismic moment tensors and GPS observations. Tectonophysics 426, 295-317. doi: 10.1016/j.tecto.2006.08.004

Van der Woerd, J., Dorbath, C., Ousadou, F., Dorbath, L., Delouis, B., Jacques, E., et al. (2014). The Al Hoceima Mw 6.4 earthquake of 24 February 2004 and its aftershocks sequence. J. Geodyn. 77, 89-109. doi: 10.1016/j.jog.2013.12.004

Vernant, P., Fadil, A., Mourabit, T., Ouazar, D., Koulali, A., Davila, J. M., et al. (2010). Geodetic constraints on active tectonics of the Wester Mediterranean:
Implications for the kinematics and dynamics of the Nubia-Eurasia plate boundary zone. J. Geodyn. 49, 123-129.

Vissers, R. L. M., Platt, J. P., and van der Wal, D. (1995). Late orogenic extension of the Betic Cordillera and the Alboran Domain: a lithospheric view. Tectonics 14, 786-803.

Walsh, J. J., Childs, C., Imber, J., Manzocchi, T., Watterson, J., and Nell, P. A. R. (2003). Strain localisation and population changes during fault system growth within the Inner Moray Firth, Northern North Sea. J. Struct. Geol. 25, 307-315.

Wang, Z. (2011). Seismic hazard assessment: issues and alternatives. Pure Appl. Geophys. 168, 11-25. doi: 10.1007/s00024-010-0148-3

Wesnousky, S. G. (1986). Earthquakes, quaternary faults, and seismic hazard in California. J. Geophys. Res. Solid Earth 91, 12587-12631.

Worrall, D. M., and Snelson, S. (1989). "Evolution of the northern Gulf of Mexico," in The Geology of North America; An Overview, eds A. W. Bally and A. R. Palmer (Boulder, CO: Geological Society of America), 97-138.

Conflict of Interest: The authors declare that the research was conducted in the absence of any commercial or financial relationships that could be construed as a potential conflict of interest.

The handling editor declared a past co-authorship with several of the authors Ed'A and AR.

Copyright (C) 2021 Tendero-Salmerón, Lafosse, d'Acremont, Rabaute, Azzouz, Ercilla, Makkaoui and Galindo-Zaldivar. This is an open-access article distributed under the terms of the Creative Commons Attribution License (CC BY). The use, distribution or reproduction in other forums is permitted, provided the original author(s) and the copyright owner(s) are credited and that the original publication in this journal is cited, in accordance with accepted academic practice. No use, distribution or reproduction is permitted which does not comply with these terms. 